\title{
Pendampingan Pencatatan dan Pembukuan Sederhana bagi Orang Pribadi sebagai Pelaku Usaha di Kelurahan Talang Jambe, Kota Palembang
}

\author{
Nilam Kesuma $^{1 *}$, Asfeni Nurullah ${ }^{1}$, dan Eka Meirawati ${ }^{1}$ \\ ${ }^{1}$ Fakultas Ekonomi, Universitas Sriwijaya, Sumatera Selatan, Indonesia \\ *Email korespondensi: nilamkesuma@fe.unsri.ac.id
}

Info Artikel: Diterima: 20 Agustus 2020; Disetujui: 23 September 2020; Dipublikasi: 16 Oktober 2020

\begin{abstract}
Abstrak: Kegiatan pengabdian kepada masyarakat ini bertujuan agar pelaku usaha memahami dasardan prosedur melakukan pencatatan dan pembukuan sederhana serta dapat membuat laporan keuangan. Talang Jambe adalah sebuah kelurahan di wilayah Kecamatan Sukarame. Mayoritas penduduk daerah ini berusaha sebagai pekerja, namun sebagian lagi dari penduduk adalah memuka usaha kecil-kecilan dibidang kuliner. Namun bertambahnya pelaku usaha tidak diiringi dengan perkembangan aspek finansial. Ini dikarenakan, minimnya motivasi dari pelaku usaha dan kurangnya kemampuan pelaku usaha dalam mengelola keuangan usaha mereka. Berdasarkan pengamatan yang dilakukan oleh tim pengabdian mengenai tingkat pemahaman peserta pelatihan, bahwa $80 \%$ peserta pengabdian memahami tentang pentingnya melakukan pencatatan dan pembukuan sederhana ini.
\end{abstract}

Kata kunci: pencatatan; pembukuan; pelaku usaha; akuntansi

Kutipan:

Kesuma, N., Nurullah, A., \& Meirawati, E. (2020). Pendampingan Pencatatan dan Pembukuan Sederhana Bagi Orang Pribadi Sebagai Pelaku Usaha di Kelurahan bagi Orang Pribadi Sebagai Pelaku Usaha di Kelurahan Talang Jambe Kota Palembang. Sricommerce: Journal of Sriwijaya Community Services, 1(2): 101-106. DOI: https://doi.org/10.29259/jscs.v1i2.18

\section{PENDAHULUAN}

Talang Jambe adalah sebuah kelurahan di wilayah Kecamatan Sukarame, Kota Palembang, Provinsi Sumatra Selatan, Indonesia. Daerah ini termasuk daerah mandiri. Sejak tahun 2010 daerah ini memisahkan diri dari kelurahan Talang Betutu. Setelah pemisahan wilayah, daerah ini semakin berkembang maju. Buah-buah dari daerah ini yang paling terkenal adalah buah pepaya atau kates, jambu, rambutan, serta hasil sayur mayur. Dalam sektor pendidikan, daerah ini memiliki Sekolah Dasar dan pesantren (SLTP-SMU). Dalam sektor pembangunan, daerah ini mulai membangun, termasuk perumahan dan ruko.

Mayoritas penduduk daerah ini berusaha sebagai pekerja, namun sebagian lagi dari penduduk adalah memuka usaha kecil-kecilan dibidang kuliner. Hal ini terlihat banyaknya dari penjualan kuliner dengan berbagai macam bentuk, rupa dan rasa. Perkembangan orang pribadi sebagai pelaku usaha terus mengalami peningkatan setiap tahun, dimulai dari memberikan pelayanan jasa, menjual barang sehari-hari dalam bentuk toko sembako dan kelontongan atau menciptakan produk kreatif dan inovatif lainnya. Ini adalah buktinya seseorang usahawan bisa lebih eksis dalam perekonomian daerah tersebut. Namun bertambahnya pelaku usaha tidak diiringi dengan perkembangan aspek finansial. Ini dikarenakan, minimnya motivasi dari pelaku usaha dan kurangnya kemampuan pelaku usaha dalam mengelola keuangan usaha mereka. Selain itu, sistem pencatatan dan pembukuan keuangan yang belum dilakukan dengan baik, mengakibatkan 
tercampurnya harta pribadi dengan harta perusahaan.

Rivai (2013) menyatakan bahwa pencatatan laporan keuangan yang sistematis memiliki manfaat, yaitu dapat memberikan informasi kas yang dapat dipercaya mengenai posisi keuangan usaha pada suatu saat tertentu, dapat memberikan informasi keuangan mengenai hasil usaha dalam satu periode akuntansi, dapat memberikan informasi-informasi yang dapat membantu pihak yang berkepentingan untuk menilai kondisi dan potensi suatu usaha. Disisi lain, juga memberikan informasi penting lainnya relevan dengan pihak yang berkepentingan lainnya, seperti pemerintah dalam hal ini bank, pajak atau lembaga terkait lainnya.

Harahap (2015) menjelaskan bahwa jenis laporan keuangan usaha yang umum, yaitu neraca atau laporan laba/rugi atau hasil usaha, laporan arus kas, laporan perusahaan posisi keuangan yang mana jenis laporan tersebut akan menyajikan informasi tentang kondisi suatu perusahaan. Kondisi ini terlihat pada saat pelaku usaha jika ditanya berapa laba atau keuntungan yang mereka peroleh dalam satu periode mereka tidak bisa menjawab secara tepat.

Berdasarkan kondisi tersebut di atas, salah satu cara untuk membatu dalam mengelola keuangan usaha mereka yaitu dengan memberikan pelatihan pencatatan dan pembukuan sederhana bagi orang pribadi pelaku usaha di Kelurahan Talang Jambe Kota Palembang.

Kegiatan PPM ini diharapkan dapat memberi bekal kepada para pelaku usaha di kecamatan Talang Jambe sehingga dapat meningkatkan kinerja keuangan usaha mereka. Penguasaan pencatatan dan pembukuan dengan mudah dan cepat akan memberikan manfaat bagi mereka dalam hal pengelolaan keuangan perusahaan. Penyajian pelatihan pencatatan dan pembukuan yang mendasarkan pada keadaan yang sebenarnya di dalam bisnis dan penggunaan pendekatan yang tepat akan menjadikan pelaku memahami materi secara mudah dan cepat. Pemahaman mereka terhadap pencatatan dan pembukuan diharapkan akan membantu pelaku usaha untuk mengelola sumber dana dan penggunaan secara cermat dan efisien sehingga pelaku usaha dapat berkembang lebih baik dan dapat meningkatkan perekonomian Indonesia. Tujuan yang ingin dicapai dengan diadakannya pelatihan ini adalah agar pengetahuan pelaku usaha dapat memahami dasar pencatatan dan pembukuan sederhana, memanami prosedur penysusuna laporan keuangan dan menghasilkan laporan keuangan yang nantinya dapat digunakan sebagai pengambilan keputusan.

\section{STUDI PUSTAKA}

Istilah pembukuan secara khususnya dikenal dengan nama akuntansi. Bagi perusahaan besar membuat pembukuan merupakan hal yang mudah karena mereka sudah memiliki akuntan yang sudah berpengalaman yang mereka jadikan karyawan untuk khusus mengerjakan pembukuan di perusahaannya. Sementara berkebalikan dengan itu, pengusaha baru atau kecil sering beranggapan kalau untuk membuat pembukuan itu sangat sulit dan rumit, sehingga mereka jarang membuat pembukuan sederhana ini.

Menurut Undang-Undang Nomor 28 Tahun 2007, pembukuan didefinisikan sebagai suatu proses pencatatan yang dilakukan secara teratur untuk mengumpulkan data dan informasi keuangan meliputi harta, kewajiban, modal, penghasilan, dan biaya, serta jumlah harga perolehan dan penyerahan barang atau jasa yang ditutup dengan menyusun laporan keuangan berupa neraca dan laporan laba rugi pada periode tersebut. Pembukuan tidak hanya dilakukan oleh Perusahaan besar saja, tetapi orang pribadi yang melakukan usaha pun harus melakukan pembukuan guna melihat apakah usaha yang dilakukannya menghasilkan keuntungan. Pencatatan dan Pembukuan transaksi juga merupakan salah satu bentuk manajemen keuangan.

Subur dan Hasyim (2014) yang menjelaskan bahwa manajemen keuangan dalam menjalankan sebuah usaha kecil mikro adalah salah satu aspek penting dalam menentukan kesuksesan suatu usaha. Dengan manajemen yang baik maka akan diperoleh laba yang jelas jumlahnya, dan akan terjadi pengambilan keputusan yang tepat. Dengan demikian, laporan pembukuan sederhana sangat penting diperlukan dan diterapkan oleh pelaku usaha dan tidak menggabungkan uang pribadi dengan usang hasil usahanya. Adapun menurut Hasibuan (dalam Maulani, 2016) menjelaskan bahwa manajemen keuangan usaha kecil pada dasarnya tidak terlepas dari fungsi manajemen itu sendiri yang meliputi kegiatan perencanaan/ planning,pengorganisasian / organizin 
pelaksanaan/pengalokasian / actuating dan pengendalian / controlling serta evaluasi (POAC).

Usaha Mikro Kecil dan Menengah (UMKM) merupakan salah satu penggerak perekonomian rakyat yang sangat tangguh dan memberikan kontribusi signifikan dalam memacu perekonomian di Indonesia. Hal ini disebabkan karena kebanyakan para pengusaha kecil dan menengah berasal dari industri keluarga atau rumahan serta daya serap UMKM terhadap tenaga kerja yang sangat besar dan dekat dengan rakyat kecil (Hapsari \& Hasanah, 2017). Selain itu, UMKM merupakan salah satu bentuk usaha yang dapat bertahan dalam krisis ekonomi yang pernah terjadi di Indonesia dan merupakan salah satu fokus program pembangunan yang dicanangkan oleh pemerintah Indonesia untuk terus berkembang dan maju. Menurut Kieso (2018), akuntansi didefinisikan secara tepat dengan menjelaskan tiga karakteristik penting dari akuntansi: (1) pengidentifikasian, pengukuran, dan pengkomunikasian informasi keuangan tentang (2) entitas ekonomi kepada (3) pemakai yang berkepentingan.

Secara umum, akuntansi dapat didefinisikan sebagai sistem informasi yang menghasilkan laporan kepada pihak-pihak yang berkepentingan mengenai aktivitas ekonomi dan kondisi perusahaan. (Warren,2018). Menurut Carl S. Warren, James M. Reeve dan Philip E. Fees (2018) Akuntansi merupakan sistem informasi yang menghasilkan laporan kepada pihak-pihak yang berkepentingan mengenai aktivitas ekonomi dan kondisi perusahaan. Sedangkan menurut Rudianto (2010), "Akuntansi adalah aktivitas mengumpulkan, menganalisis, menyajikan dalam bentuk angka, mengklasifikasikan, mencatat, meringkas, dan melaporkan aktivitas/transaksi suatu badan usaha dalam bentuk informasi keuangan".Ada dua dasar pencatatan yang dapat dipergunakan dalam akuntansi yaitu cash basis dan akrual basis.

Statement of Financial Accounting Concepts (SFAC) No.3, Elements of Financial Statements of Business Enterprises, mendefinisikan elemen-elemen yang saling berkaitan yang secara langsung berhubungan dengan pengukuran kinerja dan status dari perusahaan antara lain asset, kewajiban, ekuitas, pendapatan, beban, laba komprehensif, keuntungan, kerugian. Proses akuntansi sederhana dimulai dari identifikasi transaksi, menyiapkan dokumen sumber, menganalisis, mengidentifikasi, jurnal, posting, neraca lajur, menyiapkan laporan keuangan, dan membuat neraca penutup. (PSAK, 2019)

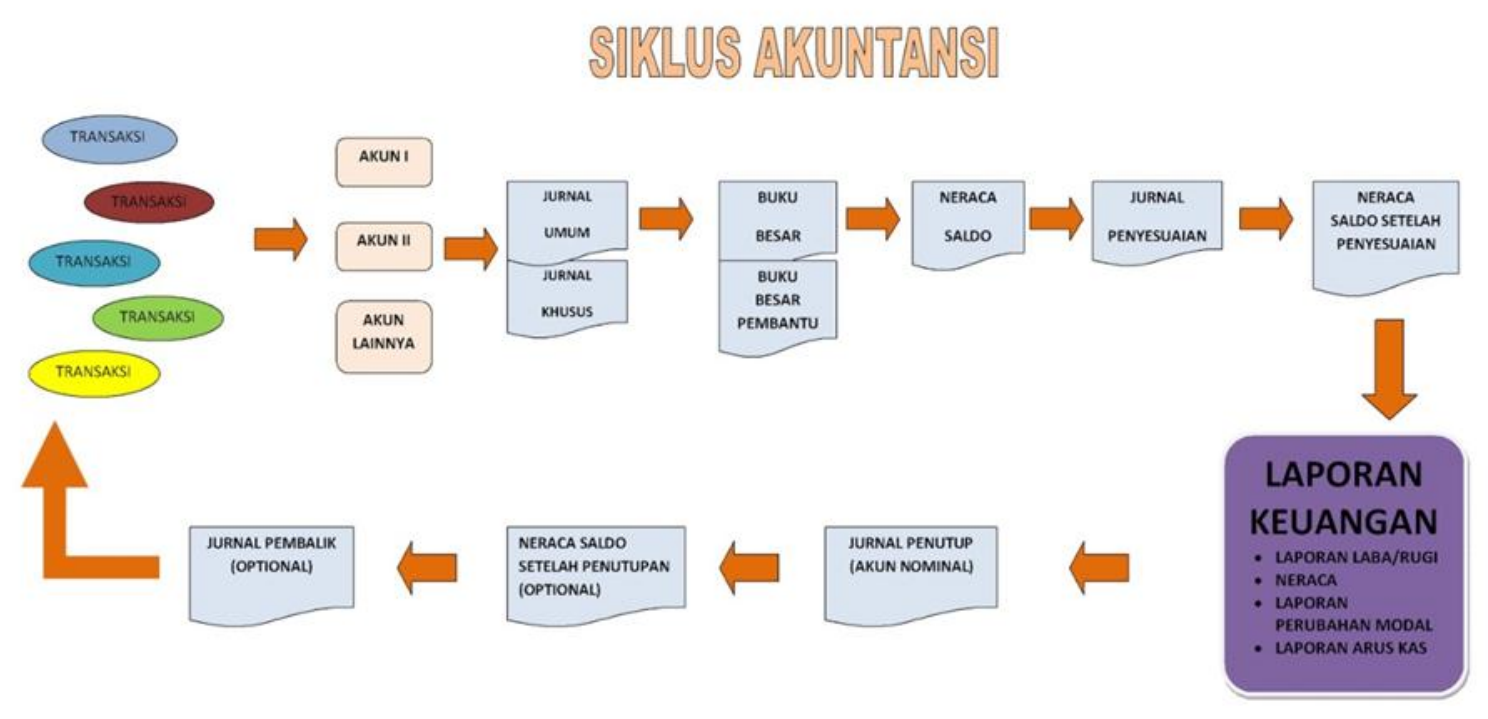

Gambar 1. Siklus Akuntansi

\section{METODE}

Metodologi pelaksanaan dalam pengabdian pada masyarakat ini dibagi menjadi 3 (tiga) tahap yaitu tahap awal, tahap pelaksanaan dan tahap akhir. Pelaksanaan kegiatan ini di Kelurahan Talang Jambe Kota Palembang yang dihadiri oleh 35 peserta yang memiliki usaha rumahan, seperti warung makan, warung sembako, konter pulsa, dan depot air minum. Jumlah peserta yang 
diharapkan hadir sebanyak 30 orang yang mewakili berbagai kegiatan usaha.

Adapun sistematika pelaksanaan kegiatan pengabdian ini adalah sebagai berikut:

a. Langkah 1 (Metode Penyuluhan):

Peserta diberikan Penjelasan mengenai pentingnya menyusun Laporan Keuangan sesuai standar dalam meningkatkan usaha.

b. Langkah 2 (praktek penggunaan aplikasi):

Peserta pelatihan diberikan materi Dasar-dasar Akuntansi, Neraca, Laporan Laba Rugi, Laporan Perubahan Modal, dan Laporan Arus Kas.

c. Langkah 3 (Diskusi):

Peserta pelatihan diberikan kesempatan untuk menyusun Laporan Keuangan dan menghitung sendiri laba rugi usaha mereka sekaligus mendiskusikan permasalahan yang berkaitan dengan permasalahan yang mereka hadapi.

\section{HASIL DAN PEMBAHASAN}

Pelaksanaan pengabdian ini berlangsung selama dua hari secara formal dan satu hari secara fleksibel. Pelatihan diawali dengan pemberian materi terkait dengan pengenalan pencatatan dan pembukuan. Kemudian dilanjutkan pemaparan tentang pentingnya akuntansi untuk pelaku usaha. Pserta diberikan materi pertama yaitu pengenalan transaksi dan pengelompokaanya. Kemudian pelatihan dilanjutkan dengan pelatihan terkait pencatatan dan pembukuan sederhana bagi pelaku usaha ini dilanjutkan dengan materi pengenalan laporan keuangan sederhana dan kegunaannya bagi pelaku usaha. Pada sesi ini terlihat peserta sangat antusias. Hal ini dikarenakan dengan adanya laporan keuangan, mereka dapat trbantu dalam pengambilan keputusan.

Selain itu, dengan adanya laporan keuangan mereka dapat melakukan pengembangan usaha, seperti pengajuan pinjaman ke bank ataupun mencari investor untuk kerjasama. Pada sesi ini juga, peserta dikenalkan dengan jenis-jenis laporan keuangan, manfaat dari laporan keuangan dan bagaimana cara membaca laporan keuangan tersebut sehingga dapat membatu mereka dalam pengambilan keputusan. Pada sesi ini, hampir semua peserta tidak memahami apa itu laporan keuangan. Bagi mereka bisa melihat jumlah kas yang diterima berbanding dengan jumlah kas yang dikeluarkan adalah laporan keuangan. Bahkan sebagian lagi dari mereka, tidak pernah mencatat berapa jumlah penghasilan mereka dalam sehari dan jumlah biaya yang mereka keluarkan dalam satu hari. Semetara utuk pelaku usaha yang memiliki persediaan barang dagangan, mereka tidak tahu bearpa nilai barang yang siap mereka jual. Dalam kegiatan usaha mereka, mereka hanya menghitung selisih harga antara mereka jual dengan mereka beli.

Pada sesi berikutnya, peserta melakukan simulasi perhitungan. Tim sudah menyiapkan sebuah kasus sederhana dilengkapai dengan kertas kerja. Pada sesi ini, peserta diajak memahami contoh kasus yang disiapkan. Kemudian dari kasus tersebut, dibuat analisis terhadap transaksi yang ada. Setelah dilakukan analisis, transaksi dikelompokkan kedalam transaksi asset, utang, modal, pendapatan atau beban. Setalh dikelompokkan lalu, peseta dicontohkan cara mencatat transaksi tersebut kedalam catatan berpasangan atau yang dikenal dengan jurnal umum. Setelah dibuat jurnal umum peserta diajak untuk memposting transaksi tersebut hingga proses akhir jadilah pembukuan sederhana. Lebih lanjut, dari buku sederhana tersebut, dijadikan sebuah laporan keuangan. Dalam laporan keuangan tersebut, peserta dipandu untuk membaca laporan keuangan. Dan hasil dari laporan keuangan tersebut peserta diminta untuk mencoba menyimpulkan kemudian memberikan tangapan atas laporan keuangannya.

Kegiatan pelatihan ini dapat berjalan dengan lancar. Hal ini disebabkan adanya faktor yang mendukung berjalan kegiatan pengabdian. Hal-hal yang mendukung berjalannya kegiatan pengabdian ini yaitu adanya dukungan Universitas Sriwijaya dan warga masyarakat kelurahan Talang Jambe yang memiliki usaha.

Pelaksanaan kegiatan pengabdian kepada masyarakat ini terbagi menjadi dua tahapan. Tahap pertama peserta diberi pengetahuan dan pelatihan mengenai pecatatan dan pembukuan sederhana. Tahap kedua, peserta diberikan pendampingan langsung dalam pelaksanaan 
pencatatan dan pembukuan sederhana ini.

Pelatihan pencatatan dan pembukuan sederhana ini bertujuan untuk meningkatan ketetampilan dan pengatahuan para pelaku usaha sehingga dapat memisahkan keuangan pribadi dengan usaha, serta para pelaku usaha dapat mengetahui perkembangan usahanya melalui pembukuan yang baik.

Berdasarkan hasil kegiatan dapat diidentifikasi berdasarkan dari evaluasi dan pengamatan yang dilakukan oleh tim pengabdian mengenai tingkat pemahaman peserta pelatihan, bahwa $80 \%$ peserta pengabdian memahami tentang pentingnya melakukan pencatatan dan pembukuan sederhana ini. Menurut peserta, dengan adanya pencatatan dan pebukuan sederhana ini, mereka dapat memisahkan harta yang mereka miliki dan harta dan kewajiban yang menjadi milik usaha mereka. Selain itu, mereka juga dapat melihat bahwa perkembangan usaha yang mereka jalankan selama ini mengalami keuntungan atau bahkan mengalami kerugian.

Dampak dan manfaat dari kegiatan pengabdian kepada masyarakat ini yaitu pelaku usaha di kelurahan Talang Jambe Kota Palembang dapat mengelola pembukuan keuangan usahanya dengan baik dan sistematis, sehingga dapat menghasilkan laporan keuangan seusai dengan standar yang berlaku, sehingga dapat membantu kelancaran bantuan dari pihak ketiga (misalnya pajak dan perbankan) yang pada akhirnya dapat membangun kekuatan usaha si pelaku usaha sehingga tercapai kesejahteraan masyarakat Indonesia secara adil dan merata.Selain itu, penerapan pembukuan sederhana juga dapat menciptakan budaya disiplin di dalam menjalan usaha dengan modal kecil. Faktor pendukung yang lain adalah adanya antusiasme peserta untuk mengikuti pelatihan ini dilihat dari tingkat kehadiran peserta sebanyak 35 peserta dari 30 peserta yang diharapkan hadir. Rangkuman kegiatan pengabdian kepada masyarakat di Kelurahan Talang Jambe Kota Palembang disajikan dalam dokumentasi sebegai berikut:

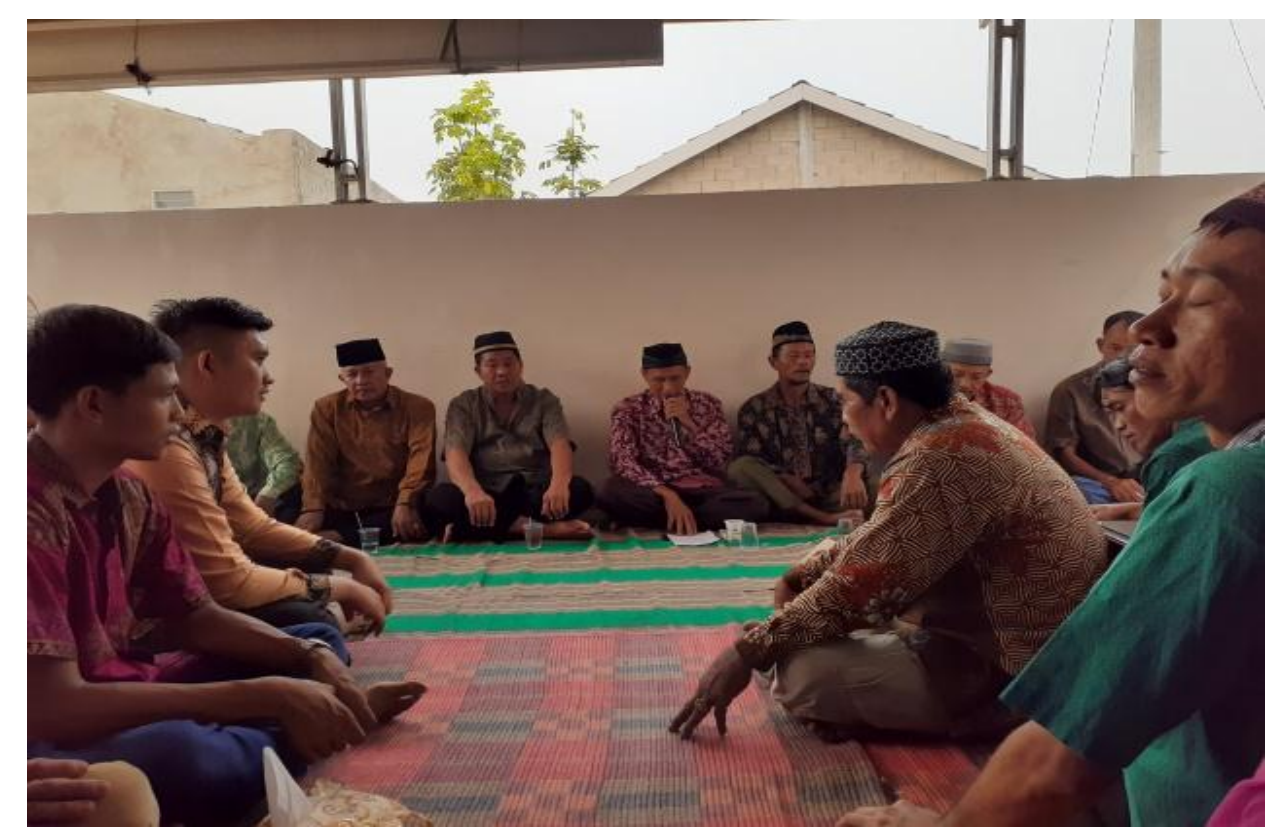

Gambar 2. Kegiatan Diskusi dan Tanya Jawab 


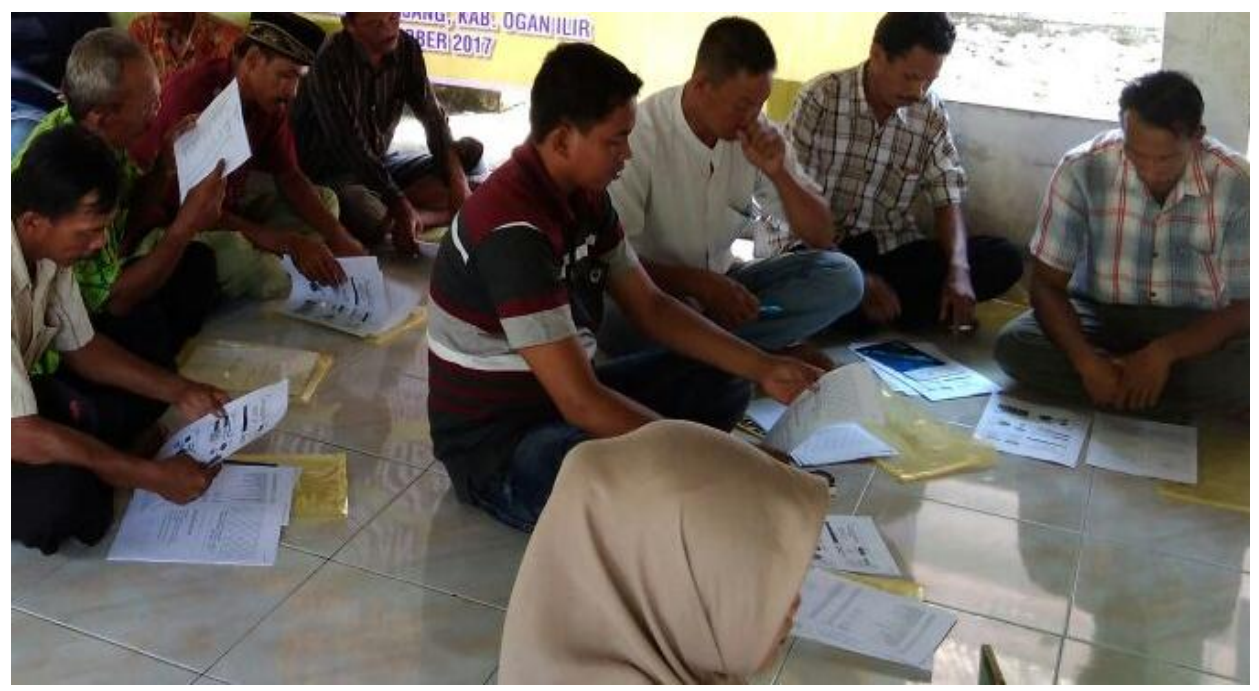

Gambar 3. Kegiatan Diskusi dan Tanya Jawab

\section{SIMPULAN}

Berdasarkan pengamatan yang dilakukan oleh tim pengabdian mengenai tingkat pemahaman peserta pelatihan, bahwa $80 \%$ peserta pengabdian memahami tentang pentingnya melakukan pencatatan dan pembukuan sederhana ini. Dari tanggapan dan pertanyaan peserta pengabdian, dalam hal ini pelaku usaha yang ada di Kelurahan Talang Jambe adanya kesinambungan program pasca kegiatan pengabdian ini sehingga masyarakat benar-benar memahami dan menyadari akan pentingnya pencatatan dan pembukuan sederhana ini bagi mereka pelaku usaha orang pribadi. Dengan adanya pencatatan dan pebukuan sederhana ini, mereka dapat memisahkan harta dan kewajiban usaha dengan harta dan kewajiban mereka pribadi.

\section{UCAPAN TERIMA KASIH}

Kegiatan Pengabdian ini didanai oleh PNBP Fakultas Ekonomi Universitas Sriwijaya. Terima kasih kepada panitia dan warga desa yang telah berpartisipasi dalam pelaksanaan kegiatan ini.

\section{REFERENSI}

Hapsari, D.P, \& Hasanah A.N. (2017). Model Pembukuan Sederhana Bagi Usaha Mikro di Kecamatan Kramatwatu Kabupaten Serang. Jurnal Akuntasi, 4(2), 36.

Harahap, S. S. (2015). Analisis Kritis Atas Laporan Keuangan. Edisi kesebelas, Jakarta: Rajawali Pers. Kieso \& Weygand. (2019). Akuntansi Intermediate, Edisi Pertama, Jakarta: Erlangga.

Ikatan Akuntan Indonesia. (2017). Standar AKuntansi Keuangan, Jakarta, Salemba Empat.

Maulani. Saptina, T. (2016). Pelatihan Pembukuan Keuangan Sederhana dan Motivasi Kewirausahaan pada Kelompok Usaha Makanan RW 02 Kelurahan Neglasari Kecamatan Cibeunying Kaler Bandung. Jurnal Dharma Bhakti STIE Ekuitas, 1(1), 32-37.

Rivai, V. (2013). Commercial Bank Management: Manajemen Perbankan dari Teori Ke Praktik Edisi 1. Jakarta: Rajawali Pers.

Rudianto. (2010). Akuntansi Koperasi Edisi Kedua. Jakarta: Erlangga.

Statement of Financial Accounting Concepts (SFAC) No.3, Elements of Financial Statements of Business Enterprises.

Subur, R.S., \& Hasyim, M. (2014). Pelatihan Manajemen Keuangan pada pelaku Usaha Toko Kelontongan Dusun Puluhan Desa Banyusidi Pakis Magelang Jawa Tengah. Jurnal Inovasi dan Kewirausahaan, 3(2), 134-140.

Warren, C.S., Reeve, J.M., Duchac, J.E., Wahyuni, E.T., Jusuf, A.A. (2018). Accounting Indonesia Adaptation. Jakarta: Salemba Empat. 